\begin{tabular}{cc|c}
\hline Tar. Bil. Der. & Tarm Bilimleri Dergisi & Journal of Agricultural Sciences \\
& $\begin{array}{c}\text { Dergi web sayfası: } \\
\text { www.agri.ankara.edu.tr/dergi }\end{array}$ & Journal homepage: \\
& www.agri.ankara.edu.tr/journal
\end{tabular}

\title{
Application of Bacteriocin-Like Inhibitory Substances (BLIS)- Producing Probiotic Strain of Lactobacillus plantarum in Control of Staphylococcus aureus in White-Brined Cheese Production
}

\author{
Meltem ÇOLAKLAR ${ }^{a}$, Birce MERCANOGLU TABAN ${ }^{\mathrm{b}}$, S. Aykut AYTAÇa, H. Barbaros ÖZER ${ }^{\mathrm{b}}$, Ayşe \\ GÜRSOY $^{\mathbf{b}}$, Nefise AKÇELIK ${ }^{\mathbf{c}}$ \\ ${ }^{a}$ Hacettepe University, Faculty of Engineering, Food Engineering Department, Beytepe, Ankara, TURKEY \\ ${ }^{\boldsymbol{b}}$ Ankara University, Faculty of Agriculture, Dairy Technology Department, Diskapi, Ankara, TURKEY \\ ${ }^{c}$ Ankara University, Biotechnology Institute, Tandogan, Ankara, TURKEY
}

\section{ARTICLE INFO}

Research Article

Corresponding Author: Birce MERCANOGLU TABAN, E-mail: btaban@ankara.edu.tr, Tel: +90 (312) 5961737

Received: 15 May 2018, Received in Revised Form: 25 August 2018, Accepted: 06 September 2018

\begin{abstract}
The aim of this study was to investigate the antimicrobial activity of an autochthonous probiotic strain of bacteriocin-like inhibitory substances (BLIS)-producing Lactobacillus plantarum, previously isolated from a Tulum cheese and satisfied technological criteria as adjunct culture in cheese production, in reducing Staphylococcus aureus during production and ripening of white-brined cheeses. Cheeses were manufactured in two trials from pasteurized milk artificially contaminated with $S$. aureus to the mean level of $6.243 \log \mathrm{MPN} \mathrm{mL} \mathrm{m}^{-1}$. Lb. plantarum BG33 was added at $1 \%$ as adjunct to the starter culture. The study was also carried out with control group cheeses produced without the adjunct culture. $S$. aureus counts were monitored for up to 90 days by BAM's 5-tube MPN method and each positive tube of MPN (most probable number) method was confirmed by PCR amplification of a $400 \mathrm{bp}$ fragment of the nuc gene, which encodes the thermostable nuclease of $S$. aureus. The capacity of $L b$. plantarum BG33 to reduce $S$. aureus count was found as 0.9 log unit on the $18^{\text {th }}$ day of ripening. After 39 and 59 days of ripening, Lb. plantarum BG33 lowered S. aureus count by 1.9 and $2.0 \log$ units, respectively, when compared to control group cheeses in which it was lowered by 0.5 and $1.0 \log$ units, respectively. As a result, the BLIS activity of $L b$. plantarum BG33 throughout ripening of white-brined cheese could make it useful as bioprotective adjunct culture in white-brined cheese production to prevent $S$. aureus growth which is an important foodborne pathogen in respect of safe cheese production.
\end{abstract}

Keywords: Lactobacillus plantarum; Staphylococcus aureus; White-brined cheese; Bacteriocin; Bio-control

(C) Ankara Üniversitesi Ziraat Fakültesi

\section{Introduction}

Traditionally manufactured cheeses especially white-brined cheeses made from thermized or raw cow's milk with a soft or semi-hard texture and a salty and acidic taste, play an important role in nutrition of people in Turkey besides being the most popular part of dairy products export of Turkey (Hayaloglu et al 2002; Temelli et al 2006). Staphylococcus aureus is a common commensal of the skin and mucosal membranes of humans. White- 
brined cheese production requires an extensive manual processing of the curd by the cheese-maker. This represents a possible route resulting in the risk of $S$. aureus contamination in white-brined cheeses and hence they could be a major cause of staphylococcal food poisoning (Rilla et al 2004; Mercanoglu Taban et al 2017).

Although there has been an improvement in cheese production facilities in dairy industries, $S$. aureus is still one of the leading pathogen that contaminates cheeses (Le Loir et al 2003; Charlier et al 2009). The frequency of $S$. aureus contamination in cheeses and the impact of staphylococcal food poisoning on public health have focused on the researches to control this pathogen. Therefore, the behaviour of $S$. aureus during production and ripening of some cheeses has been well studied (Nunez et al 1988) and many studies have been documented regarding the control of this pathogen by the direct application of bacteriocins (primarily nisin) to the cheeses (Abdalla et al 1993; Cintas et al 1998; Rilla et al 2004; Trmčić et al 2010). The use of bacteriocin-producing starter cultures in cheese production has gained the greatest interest from a food safety and human health point of view in addition with the consumers' preference of eating foods including minimum levels of chemically-synthesized additives (Rilla et al 2004). Besides, many papers have been published in combined use of various hurdles, including bacteriocins (Capellas et al 2000; Al-Holy et al 2012) or bacteriocin-producing cultures (Arques et al 2005) to inhibit foodborne pathogens in cheeses. Although the potential of bacteriocin-producing starters or adjunct cultures to control Listeria spp. in cheese production has been evaluated by a considerable amount of researches (Buyong et al 1998; O'Sullivan et al 2002; Rodriguez et al 2005), little has been known about the efficacy of using bacteriocin-producing starter or adjunct cultures on the growth and survival of $S$. aureus in cheese production (Rodriguez et al 2000; Rodriguez et al 2005; Favaro et al 2015), which may result in a better and economic way to control this pathogen in addition to the necessity of their contribution to the typical sensory characteristics and nutritional value of cheeses. For example; Rodriguez et al (2000) showed a reduction on the counts of $S$. aureus in a semi-hard cheese made with a nisinproducing starter and Rilla et al (2004) designed nisin-producing dairy starters to specifically inhibit $S$. aureus in acid-coagulated cheeses.

Considering the fact that there has still been technological drawbacks in using them as starters in industrial cheese production due to their poor acidifying, proteolytic and lypolytic characteristics and thus it is not easy to select appropriate strains having both strong technological and antimicrobial activities as starters in cheese production (Sarantinopoulos et al 2002; Favaro et al 2015), the present study aimed to evaluate antistaphylococcal ability of using autochthonous probiotic plantaricinlike bacteriocin producing Lactobacillus plantarum BG33 as adjunct culture in white-brined cheese production. The use of antistaphylococcal adjunct culture in white-brined cheese production like in this study is important in respect of dairy technology as well as food safety since there is an increasing amount of public demand for high-quality cheeses that are free of both pathogens and artificial additives.

\section{Material and Methods}

\subsection{Cultures}

Lb. plantarum BG33, previously isolated from traditional Turkish Tulum cheese and selected on the basis of its proven technological capability as adjunct culture in cheese production by Dr. M. Akcelik (Biology Department, Faculty of Science, Ankara University), were used as adjunct to the starter culture in white-brined cheese production in this study. It was cultivated routinely in MRS broth (De Man, Rogosa \& Sharpe) (Merck, Germany) at $35-37{ }^{\circ} \mathrm{C}$ for $18-24 \mathrm{~h}$ and subcultivated twice in sterile reconstituted skim milk before use in white-brined cheese production. The synthesis of plantaricin-like bacteriocin $\left(400 \mathrm{AU} \mathrm{mL}^{-1}\right)$ with low heat stability but high resistancy to lipase by $L b$. plantarum BG33, was defined in the previous study, 
including its antimicrobial and probiotic potential (Uymaz et al 2011). The reference strain of S. aureus ATCC 6538 was cultivated in tryptic soy broth (TSB; Merck, Germany) at $35-37{ }^{\circ} \mathrm{C}$ for $18-24 \mathrm{~h}$ and subcultivated twice in sterile reconstituted skim milk before use in white-brined cheese production. Frozen glycerol stock of each strain was made in sterile reconstituted skim milk supplemented with $30 \%$ glycerol and maintained at $80{ }^{\circ} \mathrm{C}$. The initial number of strains used to inoculate pasteurized cow milk was determined by streaking on the appropriate media incubated at $35-37^{\circ} \mathrm{C}$ for $18-24 \mathrm{~h}$.

\subsection{Cheese production}

To study the antimicrobial ability of BLIS-producing $L b$. plantarum BG33 to control $S$. aureus during production and ripening of white-brined cheeses, two independent vats of cheeses for each trial were conducted. Cheese production was carried out as given at Figure 1. White-brined cheeses were experimentally prepared from pasteurized cow's milk (at $75-76{ }^{\circ} \mathrm{C}$ for $1 \mathrm{~min}$ ). After warming pasteurized milk to $32-34{ }^{\circ} \mathrm{C}, 0.02 \% \mathrm{CaCl}_{2}$ (Merck, Germany), commercial mesophilic homofermentative lactic acid bacteria (LAB) (mixture of Lactococcus lactis subsp.

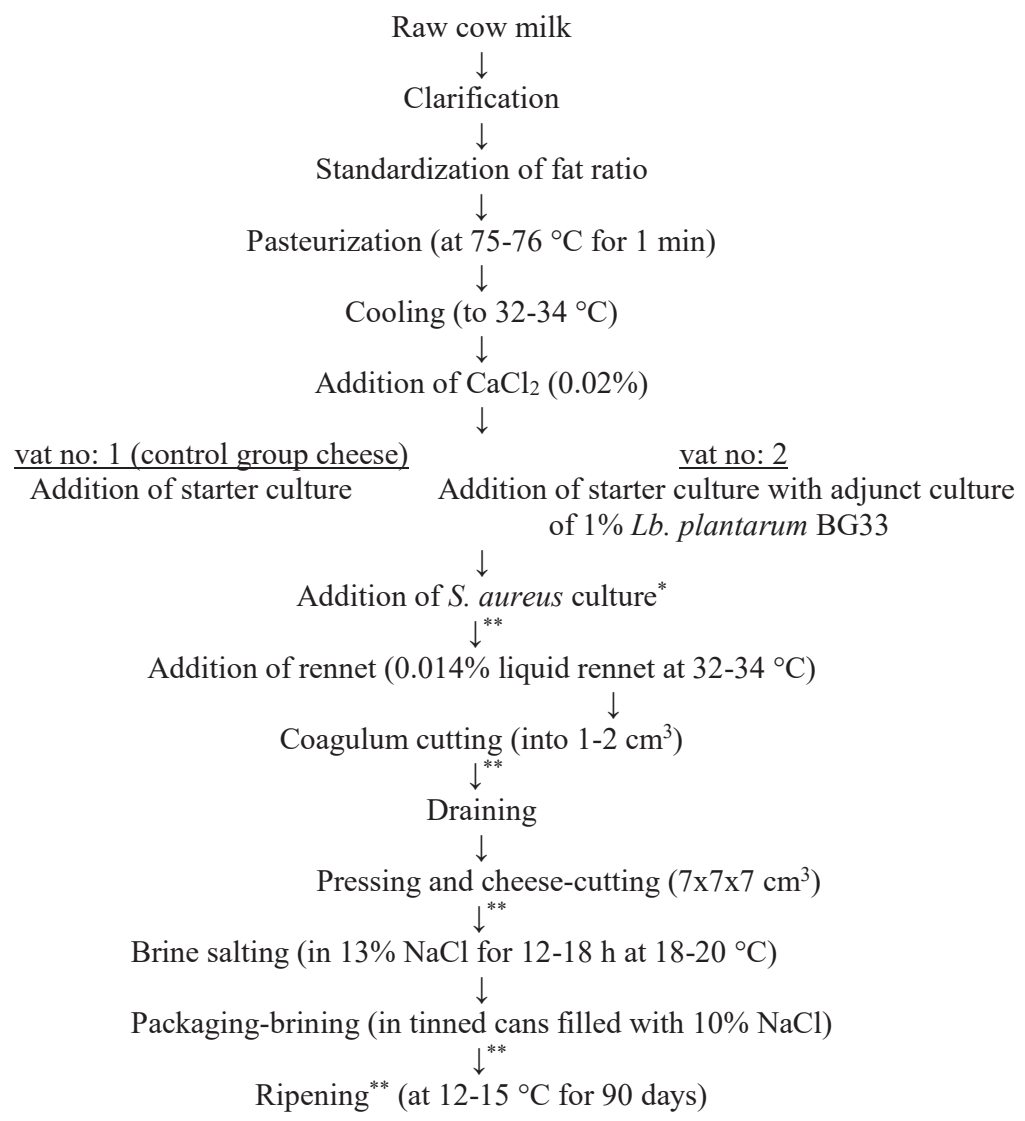

\footnotetext{
*. Vat no:1 and vat no:2 were inoculated with $S$. aureus to the mean level of $6.243 \log \mathrm{MPN} \mathrm{mL}^{-1}$; **, steps of $S$. aureus counts (just after addition of $S$. aureus culture, coagulum cutting, pressing and moulding, and packaging-brining) and on the $1^{\text {st }}, 6^{\text {th }}, 18^{\text {th }}, 25^{\text {th }}, 39^{\text {th }}, 59^{\text {th }}$, $80^{\text {th }}$, and $90^{\text {th }}$ days of ripening.
}

Figure 1- The flow diagram of white-brined cheese production with adjunct culture, including the steps of S. aureus counts in this study 
lactis and Lc. lactis subsp. cremoris, CHR Hansen R-708, Denmark) was added to the milk in each vat. Since vat no: 1 was served as control to determine the effect of production procedures for white-brined cheese on the growth of $S$. aureus added to milk at the start of the process, adjunct culture of $L b$. plantarum BG33 was only added to the vat no: 2. In other words; control cheese from pasteurized milk was made without any LAB culture, just with $S$. aureus in vat no: 1 . Then, vat no: 1 and vat no: 2 were inoculated with $S$. aureus to a final concentration of 6.243 $\log$ MPN mL ${ }^{-1}$. Next, liquid rennet (CHR Hansen Naturen ${ }^{\circledR}$ Mandra 175, 175 IMCU mL ${ }^{-1}$, Denmark) was used as a rate of $14 \mathrm{~mL} 100 \mathrm{~L}^{-1}$ milk to obtain coagulum within $90 \mathrm{~min}$. After pressing, the cheese masses were divided into blocks of about $7 \times 7 \times 7 \mathrm{~cm}^{3}$ and these blocks were salted in brine $(13 \% \mathrm{NaCl}$ for $12-18 \mathrm{~h}$ at $18-20{ }^{\circ} \mathrm{C}$ ). The brined blocks were then placed in tinned cans filled with $10 \% \mathrm{NaCl}$ and ripened at $12-15{ }^{\circ} \mathrm{C}$ for 90 days.

\subsection{Staphylococcus aureus counts}

In each trial, all cheeses were sampled at the production steps of just after addition of $S$. aureus culture, coagulum cutting, pressing-moulding, and packaging-brining and at the $1^{\text {st }}, 6^{\text {th }}, 18^{\text {th }}, 25^{\text {th }}, 39^{\text {th }}$, $59^{\text {th }}, 80^{\text {th }}$, and $90^{\text {th }}$ days of ripening. The counts of $S$. aureus were monitored by BAM's recommended 5-tube MPN method. Twenty five grams of each sample were mixed in sterile plastic bag for 1 min with $225 \mathrm{~mL}$ of $0.1 \%$ Butterfield's phosphate buffer in stomacher (Stomacher 400, the UK). One $\mathrm{mL}$ portions of decimal dilutions of each sample homogenate was inoculated into 5 tubes of tryptic soy broth (TSB) (Merck, Germany) containing 10\% $\mathrm{NaCl}$ and $1 \%$ sodium pyruvate (Merck, Germany) and these tubes were incubated at $35-37{ }^{\circ} \mathrm{C}$ for $48 \mathrm{~h}$. One loopful from each tube showing growth (turbidity) was spreaded onto the surface of prepared Petri plates on duplicate with Baird-Parker agar (Merck, Germany) and all plates were incubated at $37{ }^{\circ} \mathrm{C}$ for $48 \mathrm{~h}$. At least 1 colony suspected to be $S$. aureus from each plate was transferred to TSB and was confirmed for $S$. aureus by polymerase chain reaction (PCR) amplification of a $400 \mathrm{bp}$ region of the nuc gene.

\subsection{PCR confirmation of $S$. aureus}

The DNA isolation was performed as in the study of Mercanoglu Taban \& Aytac (2009) with a highpure PCR template preparation-HPPTP kit (Roche, Germany). The resulting template DNAs were subjected to PCR. Each PCR contained $4 \mathrm{mM} \mathrm{MgCl}$ (with $1 \times$ PCR buffer, containing $10 \mathrm{mM}$ Tris, $50 \mathrm{mM}$ $\mathrm{KCl}, \mathrm{pH} 8.3$ )(Roche, Germany), $200 \mu \mathrm{M}$ ofdNTPmix, each PCR primer at a concentration of $0.4 \mu \mathrm{M}$ [based on the sequence of thermostable nuclease gene (nuc), F166: (5'- AGT TCA GCA AAT GCA TCA CA-3') and R565: (5'-TAG CCA AGC CTT GAC GAA CT3') Cremonesi et al (2005)] (Roche, Germany), 0.04 $\mu \mathrm{M} 5 \mathrm{U} \mu \mathrm{L}^{-1}$ FastStart Taq DNA polymerase (Roche, Germany), and $3 \mu \mathrm{L}$ target DNA. The final volume was adjusted to $50 \mu \mathrm{L}$ by adding sterile ultrapure water. DNA amplification was performed in Primus 96 thermal cycler (THE-MWG, Germany) using the following conditions: initial denaturation for $5 \mathrm{~min}$ at $95{ }^{\circ} \mathrm{C}$ followed by 35 cycles of denaturation $\left(95^{\circ} \mathrm{C}\right.$ for $30 \mathrm{~s})$, annealing $\left(56^{\circ} \mathrm{C}\right.$ for $\left.30 \mathrm{~s}\right)$, and extension $\left(72{ }^{\circ} \mathrm{C}\right.$ for $\left.30 \mathrm{~s}\right)$. A final extension step $\left(72{ }^{\circ} \mathrm{C}\right.$ for $7 \mathrm{~min}$ ) was performed after the completion of the cycles. As positive control, PCRs containing template DNA extracted from the reference strain $S$. aureus ATCC 6538 was carried out. Some PCRs received ultrapure water instead of template DNA to provide negative control. Aliquots of the PCR products, along with a $100-b p$ GeneRuler DNA ladder plus (readyto-use, Fermentas, Lithuania), were loaded into 1\% agarose gel (Sigma-Aldrich, the USA) containing ethidium bromide ( $1 \mathrm{mg} \mathrm{mL}^{-1}$-Invitrogen, the USA) and submitted to electrophoresis in Trisborate EDTA buffer for $40 \mathrm{~min}$ at $125 \mathrm{~V}$. The amplified DNA fragments were visualized with InGenius gel visualization and analysis system (Syngene, the UK). The expected size of the nuc PCR product is $400 \mathrm{bp}$.

\subsection{Statistical analysis}

Comparison of means by "T test, Mann-Whitney, one way ANOVA, and Kruskal-Wallis" tests were performed using SPSS 11.5 program (SPSS Inc., the USA). Statistically significant comparative results are achieved when the significance level was $\mathrm{P}<0.01$. 


\section{Results and Discussion}

Pasteurized milk in vat no: 1 and vat no: 2 were inoculated with $S$. aureus to the mean level of $6.243 \log \mathrm{MPN} \mathrm{mL}^{-1}$. S. aureus count in pasteurized milk inoculated with $1 \%$ adjunct culture of $L b$. plantarum BG33 in vat no: 2 was firstly increased only $0.4 \mathrm{log}$ unit from pasteurized milk to 1-dayold cheese and then reduced by $0.9 \log$ unit (to the mean level of $5.309 \log$ MPN mL $\mathrm{m}^{-1}$ ) on the $18^{\text {th }}$ day (432 hours) of ripening whereas it was increased 0.7 and $0.3 \mathrm{log}$ units from pasteurized milk to 1-dayold and to 18 days (432 hours) of ripened control group cheeses, respectively. After 39 days (936 hours) of ripening, $L b$. plantarum BG33 lowered S. aureus count by $1.9 \log$ units with respect to control group cheeses in which it was lowered by only $0.5 \log$ units (Figure 2). According to the analysis of variance, $S$. aureus counts in whitebrined cheese were influenced $(\mathrm{P}<0.01)$ by addition of adjunct culture of $L b$. plantarum $\mathrm{BG} 33$ during the ripening period. This is an important reduction unit when it is considered that there is always a risk of enterotoxin accumulation at high levels of $S$. aureus contamination in foods (Lindqvist et al 2002; Akineden et al 2008; Mercanoglu Taban et al 2017).
According to the results obtained in this study, the amount of plantaricin-like bacteriocin produced by $L b$. plantarum BG33 was sufficient enough for the inhibition of high levels of $S$. aureus cells present in white-brined cheeses by $1.9 \log$ units although Abdalla et al (1993) concluded that $S$. aureus shows reduced sensitivity to bacteriocins in food matrices. Sarantinopoulos et al (2002) also concluded that the complex environment of Feta cheese, which is very similar to white-brined cheese, thoroughly interferes with bacteriocin production levels of bacteriocinogenic starter or co-cultures and there is no guarantee for their in situ antimicrobial efficiency. This is also confirmed by the study of Uymaz et al (2011) who demonstrated a greater and broad inhibitory activity of $L b$. plantarum BG33 against all the tested indicator strains, including $S$. aureus, by the agar overlay assays. In addition, it might be considered that the antimicrobial effect of this adjunct culture might show more inhibitory effect than the effect obtained in this study if the milk was contaminated with lower levels of $S$. aureus. Therefore; the high counts of $S$. aureus (mean level of $4.380 \log$ MPN mL ${ }^{-1}$ ) in white-brined cheeses produced by autochthonous probiotic strain

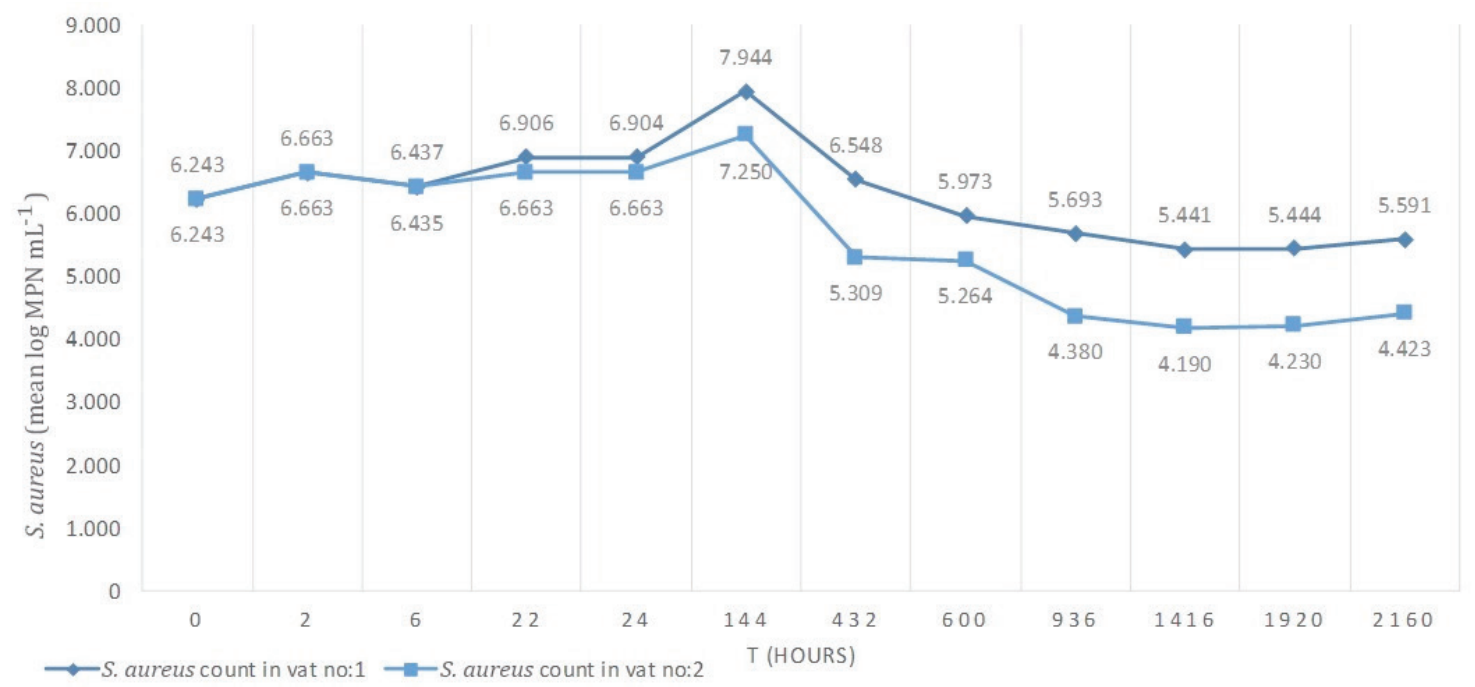

Figure 2- Survival of $S$. aureus (mean $\log M P N \mathrm{~mL}^{-1}$ ) in control group cheeses (vat no: 1) and in whitebrined cheeses produced with $1 \%$ adjunct culture of $L b$. plantarum BG33 (vat no: 2) 
of $L b$. plantarum even at the $39^{\text {th }}$ days ( 936 hours) of ripening can be based on the high inoculum level which was several log units above the levels that could be expected in naturally contaminated milk.

Beyond the direct use of bacteriocins as functional ingredients for the biopreservation of cheeses, nisin-producing lactococci have been of interest in the development of protective starter or adjunct cultures for cheese production due to their broad inhibitory activity. Therefore, most of the studies on the use of bacteriocin-producing cultures during cheese production related to them for the retardation of late gas blowing in Swiss style cheeses (O'Sullivan et al 2002). As an example; although Abdalla et al (1993) showed that $S$. aureus was not inhibited by nisin during production of white-brined cheeses from pasteurized milks and Cintas et al (1998) reported a very scarce inhibition of $S$. aureus by nisin A and pediocin PA-1, nisinproducing Lc. lactis ESI 515 which was also used as adjunct culture in cheese production was found to lower $S$. aureus count by $0.64 \log$ units on the $30^{\text {th }}$ day of cheese ripening (Rodriguez et al 2005), but a complete elimination of this foodborne pathogen was only achieved when nisin was added to process cheese spreads (Zottola et al 1994). In other words, Zottola et al (1994) showed significant reductions in numbers of Clostridium sporogenes, Listeria monocytogenes, and $S$. aureus when they used nisin-producing transconjugants of Lc. lactis ssp. cremoris JS102 and Lc. lactis ssp. lactis NCDO 1404 as starters in Cheddar cheese production. On the other hand in our study, $1.9 \log$ unit reduction on $S$. aureus count was achieved by using adjunct culture of $\mathrm{Lb}$. plantarum BG33 in white-brined cheese on the $39^{\text {th }}$ days of ripening which was far beyond better than the reduction units obtained by transformant strain Lc. lactis CL1 of Rodriguez et al (2005) and by nisin-producing Lc. lactis TAB 50 of Rodriguez et al (2000) since these cultures showed 0.98 and $0.82 \log$ units reduction on $S$. aureus counts in cheeses only after 30 days of ripening, respectively.

Likewise in our study, Rodriguez et al (2000) found that $S$. aureus count was firstly increased from pasteurized milk to 1-day-old semi-hard cheese, and then was decreased. On the contrary, El-Kholy et al (2014) evaluate the inhibition capacity of probiotic strains of Lb. acidophilus La-5 and Bifidobacterium longum ATCC 15707 on the growth of S. aureus and Escherichia coli O157:H7 during Domiati cheese production and storage and found that $L b$. acidophilus La-5 reduced $S$. aureus and E. coli O157: H7 populations in Domiati cheese by about 3 and 1.88 logs after 14 days of storage, respectively, whereas B. longum ATCC15707 reduced S. aureus and $E$. coli $\mathrm{O} 157$ : $\mathrm{H} 7$ populations in cheese by about 1.7 and $0.88 \operatorname{logs}$ after 14 days of storage, respectively, compared with the control cheeses. Hence, we also showed almost the same reduction levels of $S$. aureus with the probiotic culture of Lb. plantarum BG33 in our study.

\section{Conclusions}

Considering the consumers' current demand for zero tolerance concerning the risk for foodborne pathogen contamination in dairy products, the use of antistaphylococcal starter cultures or adjunct cultures as an alternative to chemical additives in cheese production is a point of crucial importance both in respect of dairy technology as well as food safety. Therefore in this study, the use of BLISproducing $L b$. plantarum BG33 that was previously proven to have technological capability as adjunct culture in cheese production, to control growth and survival of $S$. aureus during white-brined cheese production and ripening was investigated. This study demonstrates the potential application of plantaricin-like bacteriocin-producing autochthonous probiotic strain of $L b$. plantarum BG33 as adjunct culture in safe cheese production which is of crucial importance. Although this strain can slightly inhibit $S$. aureus growth in white-brined cheeses, due to the risk of enterotoxin production in cheese and of subsequent human intoxication, its inhibition potential of the expression of enterotoxin genes of S. aureus and antimicrobial potential in the control of other foodborne pathogens can also further be investigated. 


\section{Acknowledgements}

This research received no specific grant from any funding agency.

\section{References}

Abdalla O M, Davidson D M \& Christen G L (1993). Survival of selected pathogenic bacteria in white brined cheese made with lactic acid bacteria or antimicrobials. Journal of Food Protection 56(11): 972-976

Akineden O, Hassan A A, Schneider E \& Usleber E (2008). Enterotoxigenic properties of Staphylococcus aureus isolated from goats milk cheese. International Journal of Food Microbiology 124(2): 211-216

Al-Holy M A, Al-Nabulsi A, Osaili T M, Ayyash M M \& Shaker R R (2012). Inactivation of Listeria innocua in brined white cheese by a combination of nisin and heat. Food Control 23(1): 48-53

Arques J L, Rodriguez E, Gaya P, Medina M, Guamis B $\&$ Nunez M (2005). Inactivation of Staphylococcus aureus in raw milk cheese by combinations of highpressure treatments and bacteriocin-producing lactic acid bacteria. Journal of Applied Microbiology 98: 254-260

Buyong N, Kok J \& Luchansky J B (1998). Use of a genetically enhanced, pediocin-producing starter culture, Lactococcus lactis subsp. lactis MM217, to control Listeria monocytogenes in Cheddar cheese. Applied and Environmental Microbiology 64(12): 4842-4845

Capellas M, Mor-Mour M, Gervilla R, Yuste J \& Guamis B (2000). Effect of high-pressure combined with mild heat or nisin on inoculated bacteria and mesophiles of goat's milk fresh cheese. Food Microbiology 17(6): 633-641

Charlier C, Cretenet M, Even S \& Le Loir Y (2009). Interactions between Staphylococcus aureus and lactic acid bacteria: an old story with new perspectives. International Journal of Food Microbiology 131(1): 30-39

Cintas L M, Casaus P, Fernandez M F \& Hernandez P E (1998). Comparative antimicrobial activity of enterocin L50, pediocin PA-1, nisin A and lactocin S against spoilage and foodborne pathogenic bacteria. Food Microbiology 15(3): 289-298

Cremonesi P, Luzzana M, Brasca M, Morandi S, Lodi R, Vimercati C, Agnellini D, Caramenti G, Moroni P
\& Castiglioni B (2005). Development of a multiplex PCR assay for the identification of Staphylococcus aureus enterotoxigenic strains isolated from milk and dairy products. Molecular and Cell Probes 19(5): 299-305

El-Kholy A M, El-Shinawy S H, Meshref A M S \& Korany A M (2014). Microbiological quality of Domiati cheese and the influence of probiotics on the behavior of Staphylococcus aureus and Escherichia coli O157:H7 in Domiati cheese. Journal of Food Safety 34: 396-406

Favaro L, Lucia A, Barretto Penna A L \& Todorov S D (2015). Bacteriocinogenic LAB from cheesesApplication in biopreservation? Trends in Food Science \& Technology 41: 37-48

Hayaloglu A A, Guven M \& Fox P F (2002). Microbiological, biochemical and technological properties of Turkish white cheese 'Beyaz Peynir'Review. International Dairy Journal 12: 635-648

Le Loir Y, Baron F \& Gautier M (2003). Staphylococcus aureus and food poisoning. Genetics and Molecular Research 2(1): 63-76

Lindqvist R, Sylvén S \& Vågsholm I (2002). Qantitative microbial risk assessment exemplified by Staphylococcus aureus in unripened cheese made from raw milk. International Journal of Food Microbiology 78: 155-170

Mercanoglu Taban B \& Aytac S A (2009). Application of magnetic immuno-polymerase chain reaction assay for detection of Salmonella spp. in chicken meats. European Food Research and Technology 229: 623628

Mercanoglu Taban B, Akineden Ö, Karimihachehsoo S, Gross M \& Usleber E (2017). Enterotoxigenic Staphylococcus aureus in brined cheese from weekly street markets in Ankara, Turkey. Journal of Food Safety and Food Quality 68: 117-123

Nunez M, Bautista L, Medina M \& Gaya P (1988). Staphylococcus aureus, thermostable nuclease and staphylococcal enterotoxins in raw ewes milk Manchego cheese. Journal of Applied Bacteriology 65(1): 29-34

O'Sullivan L, Ross R P \& Hill C (2002). Potential of bacteriocin-producing lactic acid bacteria for improvements in food safety and quality. Biochimie 84(5-6): 593-604

Rilla N, Martinez B \& Rodriguez A (2004). Inhibition of a methicillin-resistant Staphylococcus aureus strain in 
Afuega'l Pitu cheese by the nisin Z-producing strain Lactococcus lactis subsp. lactis IPLA 729. Journal of Food Protection 67(5): 928-933

Rodriguez E, Arques J L, Gaya P, Nunez M \& Medina M (2000). Behaviour of Staphylococcus aureus in semihard cheese made from raw milk with nisin-producing starter cultures. Milchwissenschaft 55: 633-635

Rodriguez E, Calzada J, Arques J L, Rodriguez J M, Nunez M \& Medina M (2005). Antimicrobial activity of pediocin-producing Lactococcus lactis on Listeria monocytogenes, Staphylococcus aureus and Escherichia coli O157:H7 in cheese. International Dairy Journal 15: 51-57

Sarantinopoulos P, Leroy F, Leontopoulou E, Georgalaki M D, Kalantzopoulos G, Tsakalidou E \& De Vuyst L (2002). Bacteriocin production by Enterococcus faecium FAIR-E 198 in view of its application as adjunct starter in Greek Feta cheese making.
International Journal of Food Microbiology 72: 125136

Temelli S, Anar S, Sen C \& Akyuva P (2006). Determination of microbiological contamination sources during Turkish white cheese production. Food Control 17(11): 856-861

Trmčić A, Obermajer T, Čanžek Majhenič A, Rogelj I \& Bogovič Matijašić B (2010). In-situ inhibition of Staphylococcus aureus by lactic acid bacteria consortia from two traditional Slovenian raw milk cheeses. Mljekarstvo 60(3): 183-190

Uymaz B, Akkoc N \& Akcelik M (2011). Partial characterization of bacteriocins produced by two Lactobacillus strains with probiotic properties. Acta Biologica Hungarica 62(1): 95-105

Zottola E A, Yezzi T L, Ajao D B \& Roberts R F (1994). Utilization of Cheddar cheese containing nisin as an antimicrobial agent in other foods. International Journal of Food Microbiology 24: 227-238 